\title{
Macular Optical Coherence Tomography Angiography Parameters in Central Retinal Vein Occlusion and Differentiation of Ischemic and Non-Ischemic Types
}

\author{
Santral Retinal Ven Tıkanıklı̆ında Makuler Optik Koherens Tomografi Anjïografi \\ Parametreleri ve Iskemik ile iskemik Olmayan Tiplerin Ayrımı
}

\author{
• Şehnaz Özçalsşkan, ๑ Yasin Özcan*, ๑ Özgür Artunay
}

University of Health Sciences Turkey, Beyoglu Eye Training and Research Hospital, Clinic of Opthalmology, Istanbul, Turkey

*Yeditepe University Faculty of Medicine, Department of Ophthalmology, Istanbul, Turkey

Abstract

\begin{abstract}
Aim: To evaluate the macular microvascular parameters in central retinal vein occlusion (CRVO) and to differentiate its ischemic and non-ischemic types.

Methods: This study included 32 affected and 32 unaffected eyes of patients with unilateral CRVO and 32 age and sexmatched healthy control eyes. All participants had $6 \times 6$ scan pattern macular optical coherence tomography, optical coherence tomography angiography (OCTA) imaging. Vessel density (VD), perfusion density (PD), and foveal avascular zone area measurements of the superficial capillary plexus (SCP) were automatically calculated.
\end{abstract}

Results: There were statistically significant differences among the affected and unaffected eyes of CRVO patients and the control eyes in terms of the mean VD of the central ring and the median PD of the central and inner ring. There was a significant decrease in the mean VD and PD values of the inner and outer ring in the ischemic CRVO types compared to the non-ischemic types.

Conclusion: The results of this study showed that VD and PD in SCP were significantly affected CRVO. The alterations were more pronounced in ischemic type of CRVO. OCTA imaging may provide valuable information on early prediction of ischemic and non-ischemic CRVO types.

Keywords: Ischemia, perfusion, retinal vein occlusion
Öz

Amaç: Santral retinal ven tıkanıklığında (SRVT) makuler mikrovasküler parametrelerin değerlendirmesi ve iskemik ile iskemik olmayan tiplerin ayırt edilmesi

Yöntemler: Bu çalışmaya, tek taraflı SRVT'li olguların 32 etkilenmiş ve 32 etkilenmemiş gözü ile yaş ve cinsiyet uyumlu 32 sağlıklı kontrol gözleri dahil edilmiştir. Tüm katıımcılara 6x6 tarama paterninde makuler optik koherens tomografi anjiyografi (OKTA) görüntülemesi yapılmıştır. Yüzeyel kapiller pleksusta (SCP) damar yoğunluğu (VD), perfüzyon yoğunluğu (PD) ve foveal avasküler bölge (FAZ) alanı ölçümleri otomatik olarak hesaplanmıştır.

Bulgular: SRVT'li gözler, SRVT olgularının etkilenmeyen gözleri ve kontrol gözleri arasında santral bölge VD'si ile santral ve iç halkanın ortanca PD'si açısından istatistiksel olarak anlamlı farklılık saptandı. İç ve dış halkanın ortalama VD ve PD ölçümlerinde, iskemik olmayan tipe kıyasla, iskemik tipteki ölçümlerde istatistiksel anlamlı bir azalma saptanmıştır.

Sonuç: Bu çalışma, SRVT olgularında SCP'de VD ve PD ölçümlerinin anlamlı olarak etkilendiğini göstermiştir. Değişiklikler SRVT'nin iskemik tipinde daha belirgin saptanmıştır. OKTA görüntüleme, iskemik ile iskemik olmayan SRVT tipinde erken tahmin konusunda değerli bilgiler sağlayabilir.

Anahtar Sözcükler: İskemi, perfüzyon, retinal ven tıkanıklığı
Address for Correspondence/Yazışma Adresi: Sehnaz Özçalışkan, University of Health Sciences Turkey, Beyoglu Eye Training and Research Hospital Clinic of, Opthalmology, Istanbul, Turkey Phone: +90 2122515900 E-mail: drsehnaz@yahoo.com ORCID: orcid.org/0000-0002-3783-3570 Received/Geliş Tarihi: 18.11.2020 Accepted/Kabul Tarihi: 13.01.2021
Copyright 2021 by The Medical Bulletin of istanbul Haseki Training and Research Hospital The Medical Bulletin of Haseki published by Galenos Yayınevi. ${ }^{\circ}$ Telif Hakkı 2021 İstanbul Haseki Eğitim ve Araştıma Hastanesi Haseki Tıp Bülteni, Galenos Yayınevi tarafından yayınlanmıștı. 


\section{Introduction}

Retinal vein occlusion (RVO) is the second most common retinal vascular disease causing permanent loss of vision following diabetic retinopathy (1). Visual prognosis and outcomes are dependent on the presence of retinal ischemia and macular edema. Severe retinal ischemia causes increased vascular endothelial growth factor (VEGF) levels, which may lead to neovascularization, vitreous hemorrhage, neovascular glaucoma, and retinal detachment (2).

RVO is classified into ischemic and non-ischemic types based on non-perfused areas in fluorescein angiography (FA). FA is the gold standard for evaluating the extent of retinal ischemia and neovascularization in RVO (3). That imaging technique requires intravenous fluorescein dye injection for the acquisition of retinal images. In addition, the procedure also has side effects including renal function impairment, vomiting, nausea, and life-threatening severe allergic anaphylactoid reactions due to the fluorescein $(4,5)$.

Optical coherence tomography angiography (OCTA) is a novel, reproducible and non-invasive imaging technique that enables clinicians to visualize the retinal microvascular circulation. Moreover, different OCTA platforms also provide quantitative data of macular microvasculature. In a previous study, Casselhomde Salles et al. (6) analyzed the foveal avascular zone (FAZ) area in central retinal vein occlusion (CRVO) and observed FAZ enlargement both in superior capillary plexus (SCP) and deep capillary plexus (DCP). Koulisis et al. (7) showed a reduced vascular density of SCP in cases with macular edema due to RVO compared to that in eyes without edema. A recent study revealed decreased parafoveal vascular density values in SCP and DCP of eyes with CRVO (8). OCTA seems like a promising method for clarification of changes in macular microcirculation and evaluation of the ischemic status of RVO.

In the present study, we aimed to investigate the macular vascular parameters in SCP using OCTA and to determine whether these changes may be used in differentiation between the ischemic and non-ischemic characteristics of RVO.

\section{Methods}

\section{Study Design}

This single-center, retrospective case-control study was conducted from October 2019 to April 2020 in a tertiary referral center for retinal diseases. Informed consent was obtained from the participants before the examination, and all measurements were taken from each patient before enrollment. The study was carried out in accordance with the Declaration of Helsinki and approved by the Hamidiye
Ethics Committee of the University of Health Sciences (20/218, 12.6.2020).

\section{Participants and Examination}

This retrospective study included 32 affected and 32 fellow eyes of patients with CRVO, and 32 healthy eyes from normal subjects.

Unilateral CRVO patients with clear ocular media and a healthy fellow eye and no history for an intraocular surgical procedure or invasive intervention were included in the study. The exclusion criteria were as follows; spherical equivalent $(\mathrm{SE})>6$ diopters, axial length $(\mathrm{AL})$ $>26 \mathrm{~mm}$, media opacities preventing high-quality imaging, uncontrolled diabetes and hypertension, history of neurological diseases, myocardial infarction and stroke, history of intraocular inflammation, history of intraocular surgery other than uncomplicated cataract surgery, eye trauma, the presence of ocular hypertension, glaucoma, or any other retinal or optic disc pathology or congenital anomaly.

CRVO was diagnosed based on clinical examination findings, and retinal images. All eyes, including the healthy eyes, underwent a comprehensive ophthalmological evaluation, comprising best-corrected visual acuity (BCVA) assessment with a Snellen chart, slit-lamp biomicroscopy, intraocular pressure (IOP) measurement using Goldman applanation tonometry, axial length (AL) measurements, and fundus examination in the dilated pupil. FA was only performed in the CRVO group. BCVA was converted to the logarithm of the minimal angle of resolution (logMAR) for statistical analysis.

\section{Fundus Fluorescein Angiography}

FA imaging was performed using Spectralis (Heidelberg Engineering, Heidelberg, Germany) FA module. All CRVO patients were administered a $5 \mathrm{~mL}$ intravenous injection of $20 \%$ sodium fluorescein for the evaluation of the dye pattern and thereby the determination of non-perfused areas of retinal tissue. Angiographic photographs were taken 15-40 seconds after the injection. The presence of a non-perfused area $\geq 10$ optic disc diameter (DD) was defined as peripheral ischemia for patients with central retinal vein occlusion, and $\geq 5$ DD non-perfused area was defined as peripheral ischemia for branch retinal vein occlusion. All FA procedures were performed after the complete resolution of retinal findings in retinal vein occlusion.

\section{Optical Coherence Tomography Angiography Image Acquisition}

All CRVO subjects had OCTA on the same day with FA imaging using Cirrus 5000 HD OCT with AngioPlex (Carl Zeiss, Dublin, USA) device. Macular microvasculature was evaluated using a $6 \times 6$ volume angiography scan 
pattern centered on the fovea. Vessel density (VD), perfusion density (PD), and FAZ area measurements in the superficial capillary plexus (SCP) of the macula were automatically calculated based on an ETDRS grid using the manufacturer's software. In the ETDRS grid, inner and outer rings correspond to the parafoveal and perifoveal regions. Images with $\geq 8$ signal strength during scanning were recorded.

\section{Statistical Analysis}

Statistical analyses were performed using SPSS version 25.0. The conformity of the variables to normal distribution was assessed with the Kolmogorov Smirnov test. For variables that were normally distributed, the Independent samples t-test was used to compare the groups, and for variables that did not show normal distribution, the MannWhitney $U$ test was used. The chi-square test was applied in comparisons of the proportions of the groups. For data with normal distribution, ANOVA was used to compare the means of the study groups and the Tukey test to test the significance of pairwise differences. The MannWhitney U-test was performed to test the significance of pairwise differences using Bonferroni correction adjusted for multiple comparisons. The relationships between measurements were assessed with Spearman's Correlation test. A 5\% type-I error level was accepted as statistical significance.

\section{Results}

\section{Demographic Data}

There were 18 male and 14 female participants both in CRVO and control groups. The mean age was $60.7 \pm 11.6$ years in CRVO group and $63.3 \pm 11.8$ years in the control group. No significant differences were determined in the mean age between the CRVO patients and the healthy subjects $(p=0.39)$. There were no significant differences between the CRVO and control group in terms of mean BCVA, IOP, AL, and SE (Table 1).

\section{Optical Coherence Tomography Angiography Analysis}

The mean central macular (CMT) and ganglion cell-internal plexiform layer (GC-IPL) thicknesses were $390 \pm 134.7 \mu \mathrm{m}$ and $62.8 \pm 19.5 \mu \mathrm{m}$ in CRVO eyes, $248.2 \pm 27.1 \mu \mathrm{m}$ and $79.6 \pm 9.5 \mu \mathrm{m}$ in the fellow eyes of CRVO patients, and $258.4 \pm 23 \mu \mathrm{m}$ and $79.1 \pm 14.7 \mu \mathrm{m}$ in the control eyes, respectively. The mean GC-IPL was determined to be statistically significantly thinner, and the mean CMT was statistically significantly thicker in eyes with CRVO compared to the fellow and control group eyes ( $p<0.001$ for all comparisons).

VD and PD in the SCP were calculated as the central, inner, and outer ring in the macular region. There were statistically significant differences among the affected and fellow eyes of CRVO patients, and the control eyes in terms of the mean VD of the central ring and the median $P D$ of the center and inner ring measurements $(p<0.001$, $p<0.001$ and $p=0.04$, respectively). The comparisons of OCTA measurements and the $p$ values of eyes with CRVO, the fellow eyes of the CRVO patients, and the control eyes are presented in Table 2.

\section{Subgroup Analysis of Ischemic and Non-Ischemic Types of CRVO}

The patients were classified into ischemic and nonischemic subgroups of CRVO. There was a significant decrease in the mean VD of the inner ring and outer ring, and in the mean PD of the inner ring and outer ring measurements in the ischemic types of CRVO compared to the non-ischemic form ( $p<0.001$ for all comparisons). The subgroup analysis of OCTA measurements in the CRVO eyes and the $p$ values are given in Table 3 .

\section{Discussion}

With the increasing availability of OCTA, there has been a recent interest of researchers in the assessment of the effects of RVO on macular microvascular circulation. OCTA is a useful non-invasive method to assess vascular density, non-perfused vessels, SCP and, and macular morphology in retinal vein occlusion $(9,10)$. The results of the current study showed that the mean VD of the central ring was significantly lower, whereas the median PD in the central and inner rings of the macular SCP was found to be significantly higher.

CRVO affects both the superficial and deep plexuses of the macula. Macular capillary network abnormalities, such as capillary disruption or dilatation, mainly occurs in the DCP. The SCP is directly bonded to retinal arterioles with greater perfusion pressure and oxygen supply, which could explain why the SCP is less affected than the DCP in RVO. The other plexus, DCP is mainly comprised of venous

\begin{tabular}{|c|c|c|c|}
\hline & $\begin{array}{l}\text { CRVO group } \\
n=32\end{array}$ & $\begin{array}{l}\text { Control group } \\
n=32\end{array}$ & $p$-value \\
\hline Age, years & $60.7 \pm 11.6$ & $63.3 \pm 11.8$ & 0.39 ** \\
\hline BVCA, logMAR¥ & $0.00 \pm 0.05$ & $0.00 \pm 0.07$ & $0.62 * *$ \\
\hline IOP, mmHg¥ & $13.16 \pm 1.66$ & $13.35 \pm 2.41$ & $0.72 * *$ \\
\hline $\mathrm{AL}, \mathrm{mm} ¥$ & $23.25 \pm 0.6$ & $23.37 \pm 0.6$ & $0.92^{* *}$ \\
\hline SE, diopters $¥$ & $-0.24 \pm 0.6$ & $-0.25 \pm 0.5$ & $0.73 * *$ \\
\hline \multicolumn{4}{|c|}{$\begin{array}{l}\text { Values are presented as mean } \pm \text { SD } \\
¥ \text { ₹alues were collected from the fellow eyes in the RVO patients. } \\
\text { *Chi-square test } \\
\text { **Independent samples t-test } \\
\text { CRVO: Central retinal vein occlusion, logMAR: Logarithm of the minimal angle of } \\
\text { resolution, IOP: Intraocular pressure, AL: Axial length, SE: Spherical equivalent, } \\
\text { SD: Standard deviation }\end{array}$} \\
\hline
\end{tabular}




\begin{tabular}{|c|c|c|c|c|}
\hline & CRVO eyes & CRVo fellow eyes & Control eyes & $p$-value \\
\hline \multicolumn{5}{|c|}{ Vessel density $\left(\mathrm{mm} / \mathrm{mm}^{2}\right)$} \\
\hline Central & $9 \pm 5$ & $6.5 \pm 4.6$ & $3.6 \pm 2.2$ & $\begin{array}{l}<0.001^{*} \\
\text { CRVO-Control: }<0.001 \\
\text { Fellow-Control: } 0.02\end{array}$ \\
\hline Inner ring & $13.1 \pm 4.5$ & $13.9 \pm 5.1$ & $12.1 \pm 3.5$ & $0.27^{*}$ \\
\hline Outer ring & $13.3 \pm 4.8$ & $12.1 \pm 3.5$ & $15.2 \pm 3.4$ & $<0.20^{*}$ \\
\hline \multicolumn{5}{|c|}{ Perfusion density (\%) } \\
\hline Central & $19.3(0.2-41.7)$ & $13.9(1.6-32.6)$ & $8.2(0.4-17.3)$ & $\begin{array}{l}<0.001+ \\
\text { CRVO-Control : }<0.001 \\
\text { Fellow-control : } 0.02\end{array}$ \\
\hline Inner ring & $33.5(5.7-46.1)$ & $38.3(9.3-45.7)$ & $30.5(6-36.3)$ & $\begin{array}{l}0.04 t \\
\text { CRVO-Control : } 0.04 \\
\text { Fellow-Control : } 0.02\end{array}$ \\
\hline Outer ring & $39.9(6-49.1)$ & $44.5(12.5-48.3)$ & $38.9(12.5-46.3)$ & $0.20^{+}$ \\
\hline \multicolumn{5}{|c|}{ Faz Area $\left(\mathrm{mm}^{2}\right)$} \\
\hline & $0.25 \pm 0.1$ & $0.24 \pm 0.1$ & $0.25 \pm 0.1$ & $0.69 *$ \\
\hline \multicolumn{5}{|c|}{$\begin{array}{l}\text { Values are presented as mean } \pm \text { SD and median (minimum-maximum) values } \\
\text { ^One-Way ANOVA test and Bonferonni multiple comparisons } \\
\text { †Kruskal-Wallis test and pairwise comparisons } \\
\text { OCTA: Coherence tomography angiography, CRVO: Central retinal vein occlusio }\end{array}$} \\
\hline
\end{tabular}

\begin{tabular}{|c|c|c|c|}
\hline & \multicolumn{3}{|c|}{ CRVO eyes } \\
\hline & Ischemic $(n=18)$ & Non-ischemic $(n=14)$ & $p$-value \\
\hline \multicolumn{4}{|c|}{ Vessel density $\left(\mathrm{mm} / \mathrm{mm}^{2}\right)$} \\
\hline Central ring & $8.2 \pm 5.7$ & $10.1 \pm 3.8$ & $0.25^{*}$ \\
\hline Inner ring & $10.8 \pm 4.6$ & $16.2 \pm 1.9$ & $<0.00^{*}$ \\
\hline Outer ring & $10.6 \pm 4.3$ & $16.8 \pm 2.7$ & $<0.001^{*}$ \\
\hline \multicolumn{4}{|c|}{ Perfusion density (\%) } \\
\hline Central ring & $14.2(0.2-41.7)$ & $20.7(10.5-38.0)$ & $0.20 * *$ \\
\hline Inner ring & $28.6(5.7-44.7)$ & $41.0(30.4-46)$ & $<0.001^{* *}$ \\
\hline Outer ring & $27.0(6.0-43.0)$ & $44.0(26.4-49.1)$ & $<0.001$ ** \\
\hline \multicolumn{4}{|c|}{$\begin{array}{l}\text { Values are presented as mean } \pm \text { SD and median } \pm \text { minimum and maximum values } \\
{ }^{*} \text { By independent } t \text { test } \\
\text { **By Mann-Whitney } U \text { test } \\
\text { OCTA: Coherence tomography angiography, CRVO: Central retinal vein occlusion, SD: Standard deviation }\end{array}$} \\
\hline
\end{tabular}

collecting channels. When a venous occlusion occurs, hydrostatic pressure elevates, and perfusion decreases, and retinal hypoxia develops (11-13). In accordance with the current study, Seknazi et al. (14) reported macular microvascular abnormalities in both the SCP and DCP on OCTA, although it was also stated that the DCP seems to be more vulnerable than the SCP in RVO. Lee et al. (15) noted that the mean VD of the SCP was lower in both CRVO and BRVO eyes. The study also highlighted that the VD in SCP was most significantly associated with collateral formation, which is strongly linked to retinal ischemia. A recent study revealed a significant decrease in both SCP and DCP in BRVO and reported that the non-perfusion area in the DCP tends to be greater than that in the SCP (16).
Studies that have investigated macular microcirculation in the SCP and DCP of RVO patients suggest that both the superficial and deep plexuses are affected at different levels. Moreover, reduction in vascular perfusion and density of the DCP are more frequent and pronounced in RVO. However, the changes in the SCP and DCP VD in both ischemic and non-ischemic forms of RVO have not yet been fully elucidated $(17,18)$.

FA is the most commonly preferred technique to detect peripheral and macular ischemia in RVO, however, the DCP may not adequately be seen on FA. The evaluation of the retinal non-perfused areas is the main determining factor in the diagnosis of ischemic RVO. The presence of diffuse peripheral ischemia in RVO may cause a significant 
visual impairment due to the development of retinal and anterior segment neovascularization (3). To evaluate the retinal ischemia optimally with $\mathrm{FA}$, the disease should be in a coalescent phase and intra and sub-retinal hemorrhages should regress. However, that requires a follow-up period. In the present study, the subgroup analysis of CRVO eyes demonstrated that the mean VD and PD of SCP in the inner and outer ring were significantly decreased in the ischemic type of CRVO compared to the non-ischemic type. Consistent with these results, Khodabandeh et al. (8), also reported significantly lower VD and reduced flow density in the parafoveal macular region in ischemic CRVO compared to non-ischemic CRVO. Pellegrini et al. (19) determined a negative correlation between the extent of the non-perfused area and VD, and explained that VD reduction is associated with an increase in non-perfusion areas. Collateral vessels develop in RVO as a response to vein occlusion, and this collateral formation has strongly been associated with retinal ischemia and the extent of the non-perfused area (15). The severity of peripheral ischemia in CRVO may be associated with the grading of the decrease in the OCTA parameters. Nevertheless, vascular dilation and telangiectasias can give a false sense of increased perfusion density in CRVO eyes. That can be overcome by vessel length analysis which accepts all the vessels as having the same caliber.

The margin of the central ring in the foveal capillary network corresponds to an avascular capillary region, known as the FAZ. In the current study, no significant difference was determined in the mean FAZ measurement in the SCP on OCTA, among study groups. The FAZ measurements of the superficial capillary layer on OCTA could not be compared with the FA images because of the lack of automatized analysis in the angiography device. Other studies have revealed that the FAZ area of SCP values in OCTA is significantly larger than FA measurements and also can be easily delineated $(17,20)$. The discrepancy in the study results may have arisen from the different OCTA platforms that are used in studies.

\section{Study Limitations}

There were several limitations to this study. First, our study is limited by its retrospective design and small sample size. Secondly, a longitudinal study would be more appropriate when evaluating retinal ischemia in CRVO. Because it has been proven that $13-18 \%$ of eyes with nonischemic CRVO at baseline may convert to ischemic type at 6-18 months (21). The third limitation is the imaging artifacts with OCTA. This is particularly essential in eyes with poor visual acuity in which the artifacts may affect accurate quantification of parameters. Finally, because of the software used, a $6 \times 6$ scan pattern was used and only SCP parameters were obtained. However, this scan pattern may not provide quantitative information in the non-perfused areas. In addition, a $3 \times 3$ scan pattern would have delineated the FAZ border more accurately (22).

\section{Conclusion}

The current study demonstrated that macular microvascular parameters such as the VD and PD are significantly affected in patients with CRVO. The changes in SCP was more pronounced in the ischemic type of CRVO compared to the non-ischemic type. Thus, OCTA may be able to provide valuable information for the early prediction of the ischemic type CRVO at the initial examination before fluorescein angiography is performed. Nevertheless, further studies are needed to confirm these results.

\section{Authorship Contributions}

Analysis and Data collection: Ş.Ö., Y.Ö., Writing: Ş.Ö., Y.Ö., Peer-review: Ö.A.

Conflict of Interest: The authors declared no conflicts of interest with respect to the authorship and/or publication of this article.

Financial Disclosure: The authors received no financial support for the research and/or authorship this article.

\section{References}

1. Glanville J, Patterson J, McCool R, Ferreira A, Gairy K, Pearce I. Efficacy and safety of widely used treatments for macular oedema secondary to retinal vein occlusion: a systematic review. BMC Ophthalmol 2014;14:7.

2. Rogers SL, Mclntosh RL, Lim L, et al.Natural history of branch retinal vein occlusion: an evidence-based systematic review. Ophthalmology 2010;117:1094-101.

3. Schmidt-Erfurth U, Garcia-Arumi J, Gerendas BS, et al. Guidelines for the Management of Retinal Vein Occlusion by the European Society of Retina Specialists (EURETINA). Ophthalmologica 2019;242:123-62.

4. Leila L. Adverse effects of fluorescein angiography. Acta Ophthalmol Scand 2006;84:720-1.

5. Lu VH, Ho IV, Lee V, Hunyor AP. Complications from fluorescein angiography: a prospective study. Clin Exp Ophthalmol 2009;37:826-7.

6. Casselholmde Salles M, Kvanta A, Amrén U, Epstein D. Optical Coherence Tomography Angiography in Central Retinal Vein Occlusion: Correlation Between the Foveal Avascular Zone and Visual Acuity. Invest Ophthalmol Vis Sci 2016;57:242-6.

7. Koulisis N, Kim AY, Chu Z, et al. Quantitative microvascular analysis of retinal venous occlusions by spectral domain optical coherence tomography angiography. PLoS One 2017;12:e0176404.

8. Khodabandeh A, Shahraki K, Roohipoor R, et al. Quantitative measurement of vascular density and flow using optical coherence tomography angiography (OCTA) in patients with 
central retinal vein occlusion: Can OCTA help in distinguishing ischemic from non-ischemic type? Int J Retina Vitreous 2018;4:47.

9. Samara WA, Shahlaee A, Sridhar J, Khan MA, Ho AC, Hsu J. Quantitative Optical Coherence Tomography Angiography Features and Visual Function in Eyes With Branch Retinal Vein Occlusion. Am J Ophthalmol 2016;166:76-83.

10. Suzuki N, Hirano $Y$, Yoshida $M$, et al. Microvascular Abnormalities on Optical Coherence Tomography Angiography in Macular Edema Associated With Branch Retinal Vein Occlusion. Am J Ophthalmol 2016;161:126-32.

11. Rispoli M, Savastano MC, Lumbroso B. Capıllary network anomalıes in branch retınal veın occlusıon on optıcal coherence tomography angıography. Retina 2015;35:2332-8.

12. Bonnin S, Mané V, Couturier $A$, et al. New ınsıght ınto the macular deep vascular plexus ımaged by optıcal coherence tomography angıography. Retina 2015;35:2347-52.

13. Genevois O, Paques M, Simonutti M, et al. Microvascular remodeling after occlusion-recanalization of a branch retinal vein in rats. Invest Ophthalmol Vis Sci 2004;45:594-600.

14. Seknazi D, Coscas F, Sellam A, et al. Optıcal coherence tomography angıography in retınal veın occlusıon: Correlations Between Macular Vascular Density, Visual Acuity, and Peripheral Nonperfusion Area on Fluorescein Angiography. Retina 2018;38:1562-70.

15. Lee $H E$, Wang $Y$, Fayed $A E$, Fawzi $A A$. Exploring the relationship between collaterals and vessel density in retinal vein occlusions using optical coherence tomography angiography. PLoS One 2019;14:e0215790.
16. Kim JT, Chun YS, Lee JK, Moon NJ, Yi DY. Comparison of Vessel Density Reduction in the Deep and Superficial Capillary Plexuses in Branch Retinal Vein Occlusion. Ophthalmologica 2020;243:66-74.

17. Adhi M, Filho MA, Louzada RN, et al. Retinal Capillary Network and Foveal Avascular Zone in Eyes with Vein Occlusion and Fellow Eyes Analyzed With Optical Coherence Tomography Angiography. Invest Ophthalmol Vis Sci 2016;57:486-94.

18. Arevalo JF, Garcia RA, Wu L, et al. Radial optic neurotomy for central retinal vein occlusion: results of the Pan-American Collaborative Retina Study Group (PACORES). Retina 2008;28:1044-52.

19. Pellegrini M, Cozzi M, Staurenghi G, Corvi F. Comparison of wide field optical coherence tomography angiography with extended field imaging and fluorescein angiography in retinal vascular disorders. PLoS One 2019;14:e0214892.

20. Werner JU, Böhm F, Lang GE, Dreyhaupt J, Lang GK, Enders C. Comparison of foveal avascular zone between optical coherence tomography angiography and fluorescein angiography in patients with retinal vein occlusion. PLoS One 2019;14:e0217849.

21. Khayat $M$, Williams $M$, Lois $N$. Ischemic retinal vein occlusion: characterizing the more severe spectrum of retinal vein occlusion. Surv Ophthalmol 2018;63:816-50.

22. Ho J, Dans K, You Q, Nudleman ED, Freeman WR. Comparison of $3 \mathrm{~mm} \times 3 \mathrm{~mm}$ versus $6 \mathrm{~mm} \times 6 \mathrm{~mm}$ optical coherence tomography angıography scan sızes in the evaluatıon of nonprolıferatıve dıabetıc retınopathy. Retina 2019;39:259-64. 